\title{
A new genus Sanitubius and a revived genus Kishidaia of the family Gnaphosidae (Araneae)
}

\author{
Takahide Kamura \\ Biological Laboratory, Otemon Gakuin University, 2-1-15, Nishi-Ai, Ibaraki, \\ Osaka, 567-8502 Japan \\ E-mail: kamura@res.otemon.ac.jp
}

\begin{abstract}
Two genera of the family Gnaphosidae are reported. A new genus Sanitubius is described, and Sanitubius anatolicus (Kamura 1989) n. comb. is transferred from Herpyllus to the new genus. Kishidaia Yaginuma 1960 is revived from a synonym of Poecilochroa Westring 1874 and redescribed. Two species, Kishidaia conspicua (L. Koch 1866) n. comb. and K. coreana (Paik 1992) n. comb., are transferred from Poecilochroa to Kishidaia. Sanitubius anatolicus, Kishidaia albimaculata (S. Saito 1934) and K. conspicua are illustrated.
\end{abstract}

Key words - Araneae, Gnaphosidae, Sanitubius n. gen., Kishidaia, new genus, new combination, taxonomy.

\section{Introduction}

Herpyllus anatolicus originally described by Kamura (1989) was assigned to Herpyllus Hentz 1832 based on the correspondence of several characters to those of other known members of this genus. However, judging from the structures of male palp and female genitalia, I reconsidered that this species was misplaced in Herpyllus. In this paper, I propose a new genus for this species.

The genus Kishidaia was established by Yaginuma (1960), and only one species, K. albimaculata (S. Saito 1934), was known under this genus. Although Paik (1992a) treated Kishidaia as a junior synonym of Poecilochroa Westring 1874, I considered that these two genera are distinct from each other. Two species previously placed in Poecilochroa should be transferred to Kishidaia.

Size of posterior median eye in following descriptions means the width of the eye measured at the horizontal level.
Family Gnaphosidae

Genus Sanitubius n. gen.

[Japanese name: Mumon-tonbigumo-zoku]

Type species. Herpyllus anatolicus Kamura 1989.

Diagnosis. This genus is similar to Herpyllus Hentz 1832 , but is separated from the latter by male palp without median apophysis and by female genitalia with a pair of long ducts.

Description. Thoracic groove distinct (Fig. 1). Anterior eye row slightly recurved and posterior eye row slightly procurved as seen from above; posterior median eyes separated from each other by at least the eye size; median ocular area longer than wide, with anterior width slightly narrower than the posterior (Fig. 2). Chelicera with three teeth on promargin and one tooth on retromargin (Fig. 3). Endites slightly convergent apically (Fig. 4). Legs with scopulae on all tarsi, and metatarsi I and II; trochanters I and II without ventral notch, trochanters III and IV each with a shallow ventral notch (Fig. 5); leg IV longest, the other legs subequal to one another in length. Abdomen unicolored. Male abdomen with a dorsal scutum. Female median spinneret slightly swollen at proximal part, with five large spigots on dorso-proximal part (Fig. 6). Male palp with embolus rather short, conductor membranous, tegulum with 
median part protruding prolaterally and pushing aside subtegulum, retrolateral tibial apophysis distinct, and without median apophysis (Figs. 7-8). Epigynum with a pair of lateral furrows and copulatory openings situated anteriorly (Fig. 9). Female genitalia with a pair of long ducts situated on ventral side of spermathecae (Fig. 10).

Remarks. Herpyllus anatolicus Kamura 1989 was originally described under the genus based on having following characters: trochanters III and IV each with a shallow ventral notch; chelicera with three teeth on promargin and one tooth on retromargin; endites slightly convergent apically; female median spinneret slightly swollen at proximal part, with five spigots on dorsoproximal part; male palp with membranous conductor; epigynum with a pair of lateral furrows. However, this species also has characters which are different from those of other known species of Herpyllus; in this species male palp lacks median apophysis which is present in other members, and this species has female genitalia with a pair of long ducts, but such ducts are absent in other members. Based on these differences of structures of male palp and female genitalia I considered that a new genus must be established for this species.

Etymology. Generic name is an arbitrary combination of letters and is masculine in gender.

Sanitubius anatolicus (Kamura 1989) n. comb. [Japanese name: Nami-tonbigumo]

(Figs. 1-10)

Herpyllus anatolicus Kamura 1989, p. 112, figs. 1-9; Yaginuma et al. 1990, p. 271; Paik 1992b, p. 135, figs. 11-25; Platnick 1993, p. 656; Platnick 1997, p. 770; Tanikawa 2000, p. 124.

Specimens examined collected from Japan. HONSHU: 2 우, Mt. Tenran-zan, Han-nou-shi, Saitama Pref., 12.VII.1998 (matured in VII.1998) and 18.X.1998, T. Hiramatsu leg.; 2 우, SW of Mt. Jinba-yama, Fujino-machi, Tsukui-gun, Kanagawa Pref., 21.VI.1997, M. Ban leg.; 1우, Hayakawa, Ayase-shi, Kanagawa Pref., 17.VI.1997, M. Ban leg.; 1우, Nobi, Yokosuka-shi, Kanagawa Pref., 8.IX.1988, K. Kumada leg.; 3우, near Mt. Kirara-mine, Komono-cho, Mie-gun, Mie Pref., 400 m alt., 24.VI.1990, K. Ogata leg.; 1우, Azuchi-cho, Gamou-gun, Shiga Pref., 4.VII.1993, Y. Hatamori leg.; 1우, Ishiyama-dera, Otsu-shi, Shiga Pref., 11.VIII.1988, T. Kamura leg.; 1우, Kasagi-cho, Soraku-gun, Kyoto Pref., 29.VII-5.VIII.1985, S. Kaneno leg.; 1\}, Ninchoji, Ibarakishi, Osaka Pref., 20.VI.1992, T. Kamura leg.; 1우, Kurakuen, Nishinomiya-shi, Hyogo Pref., 5.VII.1980, H. Shimizu leg.; 1§, Shukugawa, Nishinomiya-shi, Hyogo Pref., 19.VI.1988, T. Kamura leg.; 1今, Shirakawadai, Suma-ku, Kobe-shi,
Hyogo Pref., 25.VII.1979, T. Yamano leg.; 1^, Kamagaricho, Aki-gun, Hiroshima Pref., 15.VI.1996, M. Ogawa leg. SHIKOKU: 1우, Omogo-mura, Kamiukena-gun, Ehime Pref., 20.VIII.1958, K. Nakahira leg. KYUSHU: 1§, Mt. Tachibana-yama, Fukuoka Pref., 20.V-3.VI.1979, K. Yamagishi leg.; 1우, Mt. Hiko-san, Soeda-machi, Tagawagun, Fukuoka Pref., 4-9.VIII.1958, C. Okuma leg.

Described by Kamura (1989) as Herpyllus anatolicus.

Measurements (variation). Body length $\hat{\delta}$ 3.8-5.5 $\mathrm{mm}$, 우 5.3-7.3 mm. Carapace length 웅 $1.6^{-2.4} \mathrm{~mm}$, 우 2.3-2.9 mm; width 오 $1.25-1.8 \mathrm{~mm}$, 우 $1.6-2.1 \mathrm{~mm}$.

Distribution. Japan (Honshu, Shikoku and Kyushu), Korea (Paik 1992b).

Genus Kishidaia Yaginuma 1960

[Japanese name: Buchi-washigumo-zoku]

Kishidaia Yaginuma 1960, p. 122, append. 7.

Type species. Kishidaia quadrimaculata Yaginuma 1960 (=Castianeira albimaculata S. Saito 1934).

Diagnosis. This genus is similar to Poecilochroa Westring 1874, Sergiolus Simon 1891, Nodocion Chamberlin 1922 and Phaeocedus Simon 1893 in having a carina on cheliceral promargin, but is separated from them by having a distinct tooth on cheliceral retromargin and by lacking median apophysis in male palp. This genus also resembles Aphantaulax Simon 1878 in the condition of cheliceral margins, but differs from it by the following points: male palpal femur has a ventral projection, thoracic groove is distinct, and posterior median eyes are separated from each other by only slightly more than the eye size.

Description. Thoracic groove distinct. Anterior eye row slightly recurved and posterior eye row almost straight as seen from above; posterior median eyes separated from each other by slightly more than the eye size; median ocular area longer than wide, with anterior width narrower than the posterior (Fig. 12). Cheliceral promargin with a minute tooth and a carina not divided into distinct teeth, and retromargin with one tooth (Fig. 13). Endites rather long and slightly convergent apically (Fig. 14). Legs with scopulae on all tarsi, and metatarsi I and II; trochanters I and II without ventral notch, trochanters III and IV each with a shallow ventral notch; leg formula 4-1-2-3. Abdomen with white markings (Fig. 11). Male abdomen with a dorsal scutum. Female median spinneret almost cylindrical (Fig. 15). Male palp 


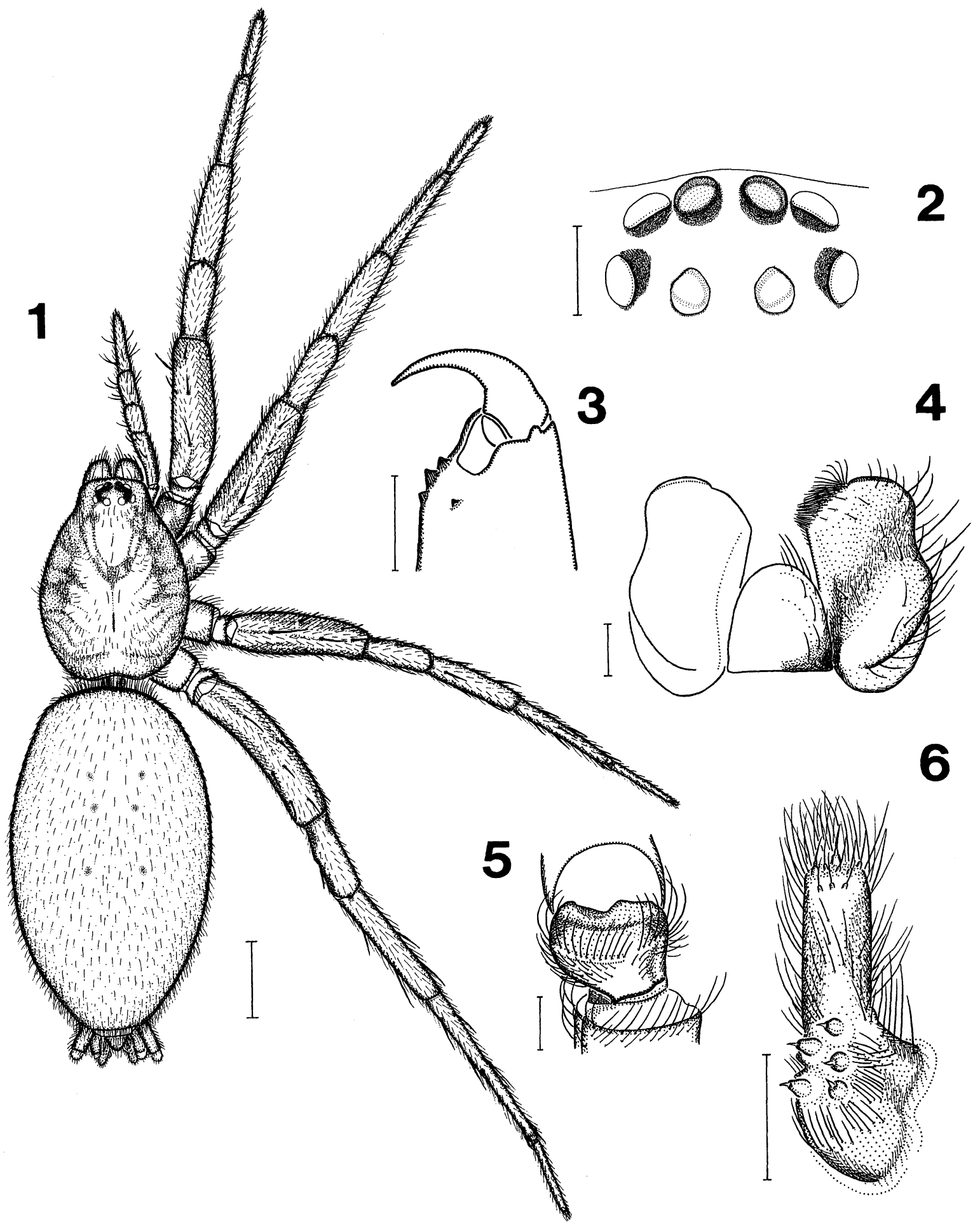

Figs. 1-6. Sanitubius anatolicus (Kamura 1989) (1, Shiga Pref.; 2 \& 5, Hyogo Pref.; 3-4 \& 6, Kyoto Pref.) 1 , Female, dorsal view; 2 , eye area, dorsal view; 3 , left chelicera, posterior view; 4 , endites and labium, ventral view; 5 , trochanter of fourth left leg, ventral view; 6 , left female median spinneret, postero-dorsal view. (Scales: $1,1.0 \mathrm{~mm} ; 2-6,0.2 \mathrm{~mm})$ 

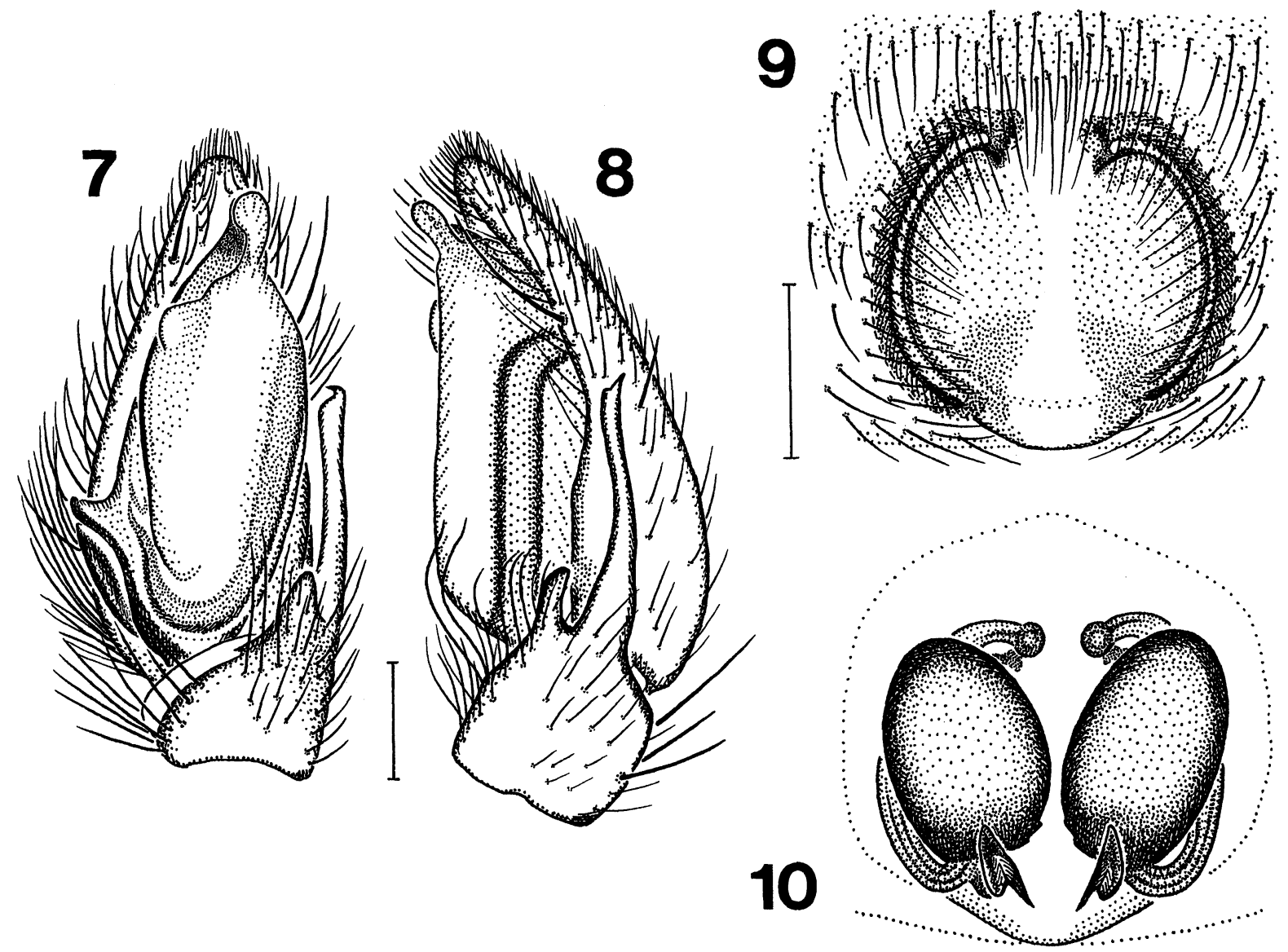

Figs. 7-10. Sanitubius anatolicus (Kamura 1989) (7-8, Fukuoka Pref.; 9-10, Hyogo Pref.) - 7, Left male palp, ventral view; 8 , same, retrolateral view; 9 , epigynum, ventral view; 10, female genitalia, dorsal view. (Scales: $0.2 \mathrm{~mm}$ )

with embolus rather short, conductor membranous, and retrolateral tibial apophysis short, and without median apophysis (Figs. 16-19, 24-27). Male palpal femur with a ventral projection on basal part (Fig. 20). Epigynum with a pair of small pockets and a shallow longitudinal furrow in anterior part (Figs. 21, 28). Female genitalia with spermathecae elongate, and a pair of small lobes situated medianly (Figs. 22, 29).

Remarks. Poecilochroa, Sergiolus, Nodocion and Phaeocedus are similar to one another in lacking teeth on cheliceral retromargin and having a carina on cheliceral promargin and male palp with massive tegulum, short and stout embolus and distinct median apophysis. The absence of retromarginal cheliceral teeth may be a synapomorphic character for these genera because in almost gnaphosid genera cheliceral retromargin has one or more teeth and the reduction of teeth is considered as apomorphic.

On the other hand, Kishidaia has different characters from those stated above. In this genus, although cheliceral promargin has a carina which is similar to that of above genera, cheliceral retromargin has a distinct tooth and male palp lacks median apophysis. These differences are enough to separate Kishidaia from the group of above four genera. Although Paik (1992a) synonymized Kishidaia with Poecilochroa, his treatment is unacceptable by above reasons.

Kishidaia rather resembles Aphantaulax in condition of cheliceral margins (pro- and retromargin have a carina and a tooth respectively) and structure of male palp (median apophysis is lacking). However, some differences are found between these genera; in Kishidaia femur of male palp has a ventral projection on basal part, thoracic groove is distinct, and posterior median eyes are separated from each other by slightly more than the eye size, while in Aphantaulax male palpal femur has no projection, thoracic groove is indistinct, and posterior median eyes are widely separated (two times the eye size). Therefore I considered that these two genera are distinct from each other. 
Kishidaia albimaculata (S. Saito 1934)

[Japanese name: Yotsuboshi-washigumo]

(Figs. 11-23)

Castianeira albimaculata S. Saito 1934, p. 292, pl. 12 (fig. 11), pl. 14 (fig. 49); S. Saito 1939, p. 35; S. Saito 1959, p. 146 , pl. 25 (fig. 200), pl. 26 (fig. 200); Roewer 1954, p. 609; Bonnet 1956, p. 961.

Kishidaia quadrimaculata Yaginuma 1960, p.122, append. 8, pl. 56 (fig. 334), figs. 100 (6), 101 (M); Yaginuma 1961, p. 6; Yaginuma 1986, p. 189, pl. 50 (fig. 10), fig. 104 (3).

Kishidaia albimaculata: Yaginuma 1970, p. 676; Yaginuma 1974, p. 205; Yaginuma 1977, p. 404; Kamura 1986, p. 13, figs. 10-18; Chikuni 1989, pp. 119 (fig. 8), 249; Platnick 1989, p. 477; Yaginuma et al. 1990, p. 271; Platnick 1993, p. 656.

Poecilochroa albimaculata: Platnick 1997, p. 780; Marusik
\& Koponen 2000, p. 60; Tanikawa 2000, p. 124.

Specimens examined collected from Japan. HOKKAIDO: 1ㅇ, Mt. Rebun-dake, Rebun Island, 2.IX.1991, N. Yasuda leg.; 1ో, Mt. Rishiri, Rishiri Island, 1.VII.1990, N. Yasuda leg.; 1ई, Sarobetsu, Teshio-gun, 11.VII.1991, N. Yasuda leg.; 1今, Shiretoko Peninsula, 2628.VII.1987, S. Kaneno leg.; 1令, near Shiretoko-goko, Sharicho, Shari-gun, 24.VII.1991, T. Kamura leg.; 1ㅇ, On-nenai, Tsurui-mura, Akan-gun, 4.VII.1992, S. Kaneno leg.; 1우 Miyajima-misaki, Tsurui-mura, Akan-gun, 30.VII2.VIII.1991, S. Kaneno leg.; 1ㅇ, Tsuruoka, Kushiro-shi, 15.VII.1977, K. Kumada leg.; 1우, Ashoro-cho, Ashoro-gun, 18-21.VII.1958, Y. Miyatake leg.; 1今, Shikaribetsu, Otofuke-cho, Kato-gun, 2-4.VIII.1956, O. Sato leg.; 1우,

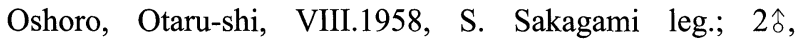
Asarigawa-onsen, Otaru-shi, 17-24.VI.1986, Y. Yoshiyasu \& S. Ikejiri leg.; 1우, Ohtaki-mura, Usu-gun, 18.VI.1986, S. Ikejiri leg. HONSHU: 1ㅇ, Mt. Murone-yama, Higashi-iwaigun, Iwate Pref., 18.VI.1964, M. Ohno leg.; 1우, Tachibana, Ohdate-shi, Akita Pref., 27-29.VI.1995, Y. Shirota leg.; 1우,

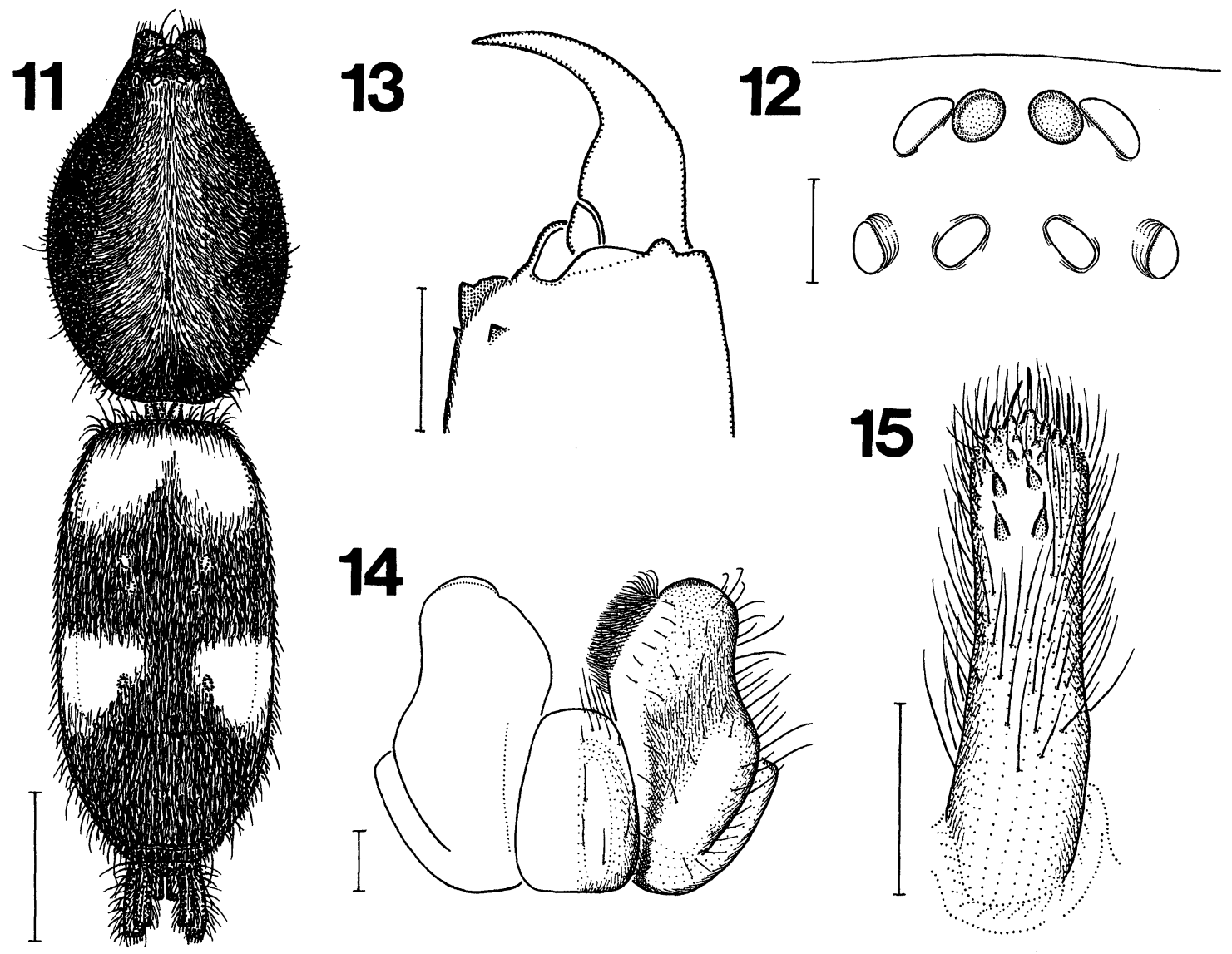

Figs. 11-15. Kishidaia albimaculata (S. Saito 1934) (11, Kyoto Pref.; 12, Iwate Pref.; 13 \& 15, Hokkaido; 14 , Hyogo Pref.) - 11, Male body, dorsal view; 12, eye area, dorsal view; 13, left chelicera, posterior view; 14, endites and labium, ventral view; 15, left female median spinneret, dorsal view. (Scales: 11, $1.0 \mathrm{~mm} ; 12-15,0.2$ $\mathrm{mm})$ 


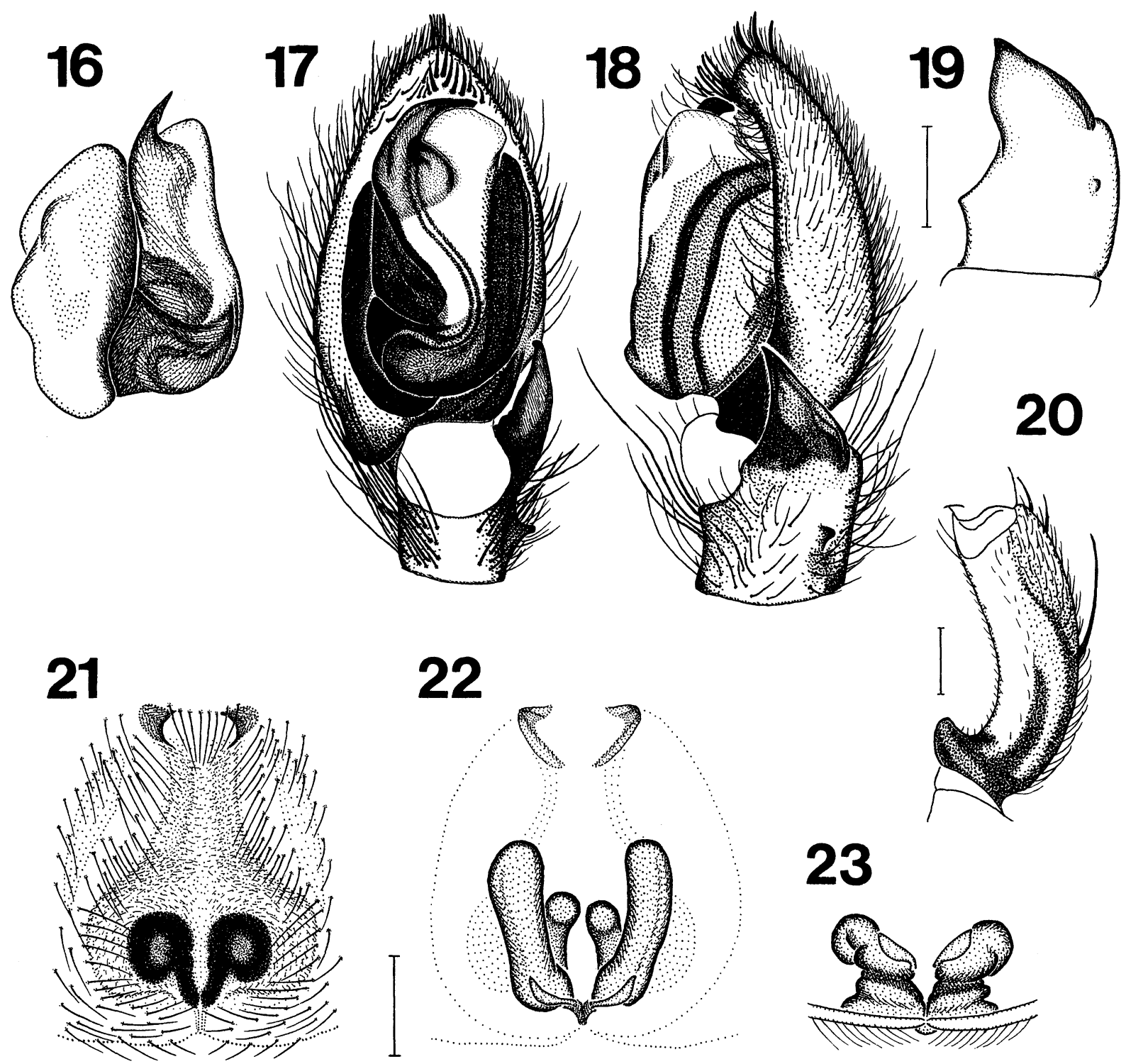

Figs. 16-23. Kishidaia albimaculata (S. Saito 1934) (16, 19 \& 21-23, Hokkaido; 17-18 \& 20, Kyoto Pref.) - 16, Bulb of left male palp, prolateral view; 17, male palp, ventral view; 18, same, retrolateral view; 19, tibia of left male palp, retrolateral view; 20, femur of left male palp, retrolateral view; 21, epigynum, ventral view; 22, female genitalia, dorsal view; 23, same, posterior view. (Scales: $0.2 \mathrm{~mm}$ )

Nikko-shi, Tochigi-Pref., 9.VII.1956, S. Kimoto leg.; 1ㅅ, Owakudani, Hakone-machi, Ashigara-shimo-gun, Kanagawa Pref., 1.VIII.1986, S. Sato leg.; 1우, Takanami-ike, Itoigawashi, Niigata Pref., 26.VII.1972, M. Ohno leg.; 1우, Oshinomura, Minami-tsuru-gun, Yamanashi Pref., 2.VIII.1980, S. Matsumoto leg.; 1우, Oiwake, Karuizawa-machi, Kita-sakugun, Nagano Pref., 25.VII.1971, S. Matsumoto leg.; 1우, SSW of Mt. Kamuriki-yama, Sakai-mura, Higashi-chikumagun, Nagano Pref., 31.V.1993, Y. Nishikawa leg., 1우, Izumi, Shirakawa-cho, Kamo-gun, Gifu Pref., 6.VIII.2000, M. Ban leg.; 1우, Ichinose, Shiramine-mura, Ishikawa-gun, Ishikawa Pref., date unknown, J. Taka leg.; 1우, Danto-uradani, Shitara-cho, Kita-shitara-gun, Aichi Pref., 940 m alt.,
24.VI.1987, K. Ogata leg.; 1^, N of Mt. Tsuzumiga-dake, Miyazu-shi, Kyoto Pref., 2.VII.1984, T. Kamura leg.; 1우, Mt. Myoken-zan, Kawanishi-shi, Hyogo Pref., 2.VII.1954, C. Takeya leg.; 2오, Mt. Daisen, Saihaku-gun, Tottori Pref., 14.VI.1965, collector unknown; 1우, Rakuzan, Matsue-shi, Shimane Pref., 14.VI.1965, collector unknown.

Diagnosis. This species is closely related to Kishidaia conspicua (L. Koch 1866) n. comb., but is distinguished from the latter by the following points: embolus of male palp is smooth (Figs. 16-17) and spermathecal bases of female genitalia are small (Figs. 22-23) in $K$. albimaculata, while in $K$. conspicua 
embolus is folded (Figs. 24-25) and spermathecae have large sclerotized bases in posterior part (Figs. 29-30). In addition, they are also different from each other in the shape of retrolateral tibial apophysis of male palp (Figs. $18-19 \& 27)$.

Described by Kamura (1986).

Measurements (variation). Body length $\hat{\circ}$ 4.4-6.45 $\mathrm{mm}$, ㅇ $6.6^{-}-9.7 \mathrm{~mm}$. Carapace length o $2.15-2.85 \mathrm{~mm}$, 우 2.9-3.8 mm; width 옹 $1.45-2.0 \mathrm{~mm}$, 우 $1.9-2.5 \mathrm{~mm}$.

Remarks. In this species, abdomen has usually distinct white markings, but the markings are rarely indistinct.

Distribution. Japan (Hokkaido and Honshu), Russia (Marusik \& Koponen 2000).

Kishidaia conspicua (L. Koch 1866) n. comb.

(Figs. 24-30)
Melanophora conspicua L. Koch 1866, p. 149, pl. 6 (figs. 90-92).

Poecilochroa conspicua: Simon 1878, p. 159; Roewer 1954, p. 429; Bonnet 1958, p. 3732; Grimm 1985, p. 164, figs. 190-192; Platnick 1989, p. 482; Platnick 1993, p. 663; Platnick 1997, p. 780.

For other literature see Roewer (1954), Bonnet (1958), Grimm (1985) and Platnick (1989, 1993, 1997).

Specimens examined. 1ำ우, Walldorf, Hessen, Germany, 9.VI.1957, H. Hesse leg. (Senckenberg-Mus., Frankfurt-M., No. 10745).

Described by Grimm (1985) as Poecilochroa conspicua.

Remarks. This species has been known under Poecilochroa for long time, but the general appearance and the structures of male palp and female genital organ of this species are very similar to those of Kishidaia albimaculata. It is clear that this species is a member of Kishidaia. As for the discrimination, see the diagnosis of K. albimaculata.
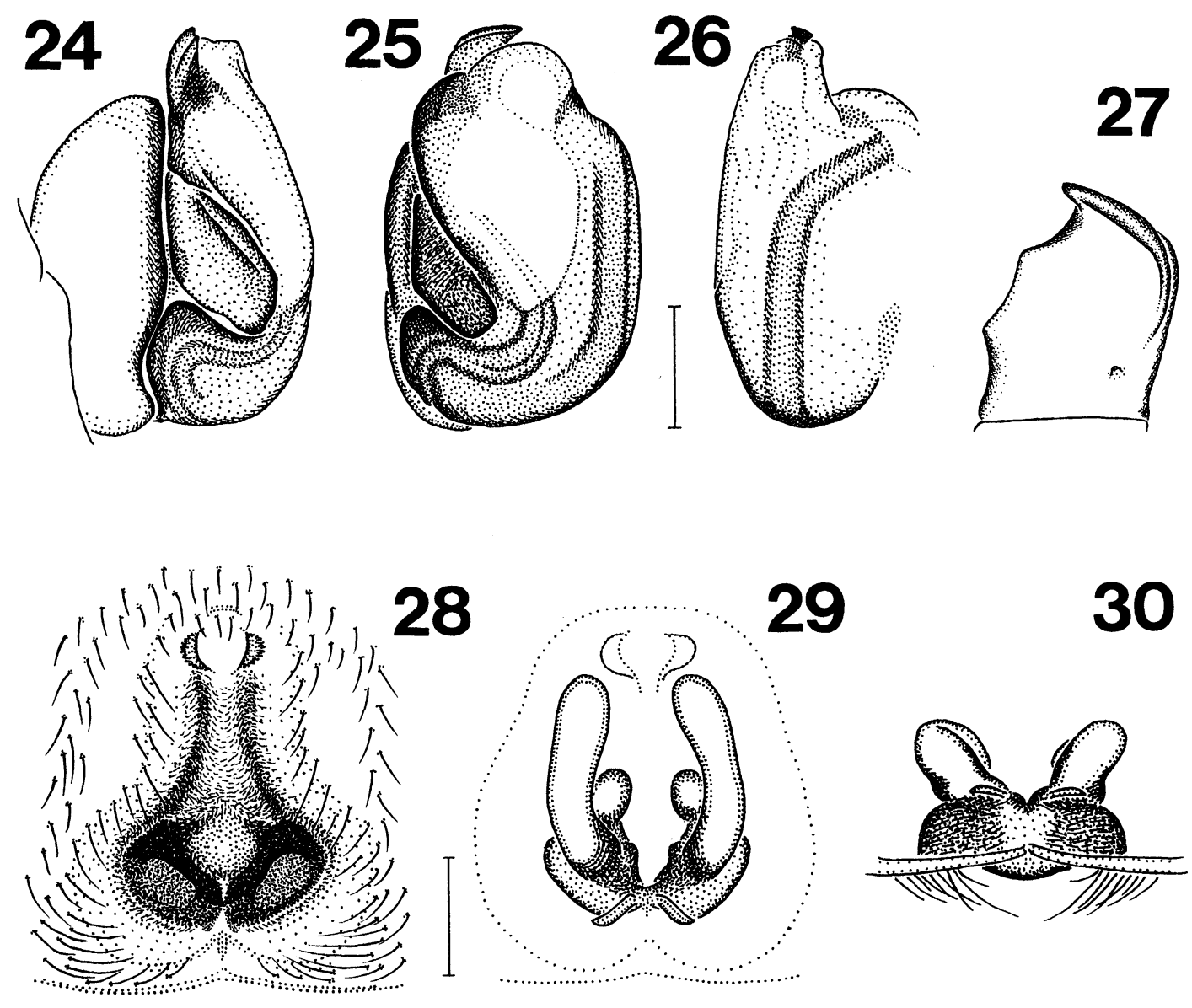

30

Figs. 24-30. Kishidaia conspicua (L. Koch 1866) (Hessen, Germany) - 24, Bulb of left male palp, prolateral view; 25, same, ventral view; 26, same, retrolateral view; 27, tibia of left male palp, retrolateral view; 28, epigynum, ventral view; 29, female genitalia, dorsal view; 30, same, posterior view. (Scales: $0.2 \mathrm{~mm}$ ) 
Distribution. Europe to Central Asia (Platnick 1997).

Kishidaia coreana (Paik 1992) n. comb.

Poecilochroa coreana Paik 1992a, p. 118, figs. 1-11; Platnick 1997, p. 780.

Remarks. Judging from the original description, this species is related to the above two species. Although I had no opportunity to examine the specimens of this species, I considered that it belongs to Kishidaia.

\section{Acknowledgments}

I wish to express my sincere thanks to Dr. Manfred Grasshoff, Senckenberg Museum, Frankfurt, for loaning the specimens of Poecilochroa conspicua and Dr. Norman I. Platnick, American Museum of Natural History, New York, for loaning the specimens of several species for comparison. My thanks are also due to the following persons for their offering or loaning the specimens used in this study: Mr. Mitsuru Ban, Kanagawa, Ms. Yuki Hatamori, Osaka, Mr. Takehisa Hiramatsu, Saitama, Mr. Hiroyoshi Ikeda, Kanagawa, Mr. Shuji Ikejiri, Shiga, Mr. Susumu Kaneno, Osaka, Mr. Ken-ichi Kumada, Mie, Mr. Seiji Matsumoto, Tokyo, Dr. Yoshiaki Nishikawa, Osaka, Mr. Kiyoto Ogata, Aichi, Mr. Mitsuaki Ogawa, Hiroshima, Dr. Hirotsugu Ono, Tokyo, Mr. Hiroyuki Shimizu, Hyogo, Mr. Jun-ichiro Taka, Ishikawa, Dr. Hozumi Tanaka, Osaka, Mr. Tadakiyo Yamano, Osaka, Mr. Nobuki Yasuda, Hokkaido, Dr. Yutaka Yoshiyasu, Kyoto, the late Dr. Chiyoko Okuma, and the late Dr. Takeo Yaginuma.

\section{References}

Bonnet, P. 1956. Bibliographia Araneorum, 2(2). Toulouse, pp. 919-1926.

Bonnet, P. 1958. Bibliographia Araneorum, 2(4). Toulouse, pp. $3027-4230$.

Chikuni, Y. 1989. Pictorial Encyclopedia of Spiders in Japan. Kaiseisha, Tokyo, 308 pp. (In Japanese)

Grimm, U. 1985. Die Gnaphosidae Mitteleuropas (Arachnida, Araneae). Abh. Naturwiss. Ver. Hamburg (NF), 26: 1-318.

Kamura, T. 1986. Notes on Japanese gnaphosid spiders (II). Atypus, 87: 9-20. (In Japanese)

Kamura, T. 1989. A new species of the genus Herpyllus (Araneae: Gnaphosidae) from Japan. pp. 111-115. In: Nishikawa, Y. and Ono, H. (ed.) Arachnological Papers Presented to Takeo Yaginuma on the Occasion of his Retirement. Osaka Arachnologists' Group, Osaka. 196 pp.

Koch, L. 1866. Die Arachnidenfamilie der Drassiden. 1. Nürnberg, pp. 1-191.

Marusik, Y. M. \& Koponen, S. 2000. New data on spiders (Aranei) from the Maritime Province, Russian Far East. Arthropoda Selecta, 9: 55-68.

Paik, K. Y. 1992a. Three new species of the genus Poecilochroa (Araneae: Gnaphosidae) from Korea. Korean Arachnol., 7: 117-130.

Paik, K. Y. 1992b. Korean spider of the genus Herpyllus (Araneae: Gnaphosidae). Korean Arachnol., 7: 131140.

Platnick, N. I. 1989. Advances in Spider Taxonomy 19811987. Manchester Univ. Press, Manchester and New York, $673 \mathrm{pp}$.

Platnick, N. I. 1993. Advances in Spider Taxonomy 19881991. New York Entomol. Soc. and Am. Mus. Nat. Hist., New York, 846 pp.

Platnick, N. I. 1997. Advances in Spider Taxonomy 19921995. New York Entomol. Soc. and Am. Mus. Nat. Hist., New York, 976 pp.

Roewer, C.F. 1954. Katalog der Araneae, 2(a). Bruxelles, $923 \mathrm{pp}$.

Saito, S. 1934. Spiders from Hokkaido. J. Fac. Agr. Hokkaido Imp. Univ., 33: 267-362, pls. 12-15.

Saito, S. 1939. On the spider from Tohoku (Northernmost part of the main island), Japan. Saito Ho-on Kai Mus. Res. Bull., 18: 1-91, pl. 1.

Saito, S. 1959. The Spider Book Illustrated in Colours. Hokuryukan, Tokyo, 194 pp., 28 pls. (In Japanese)

Simon, E. 1878. Les Arachnides de France, 4. Paris, pp. 1334, pls. $12-16$.

Tanikawa, A. 2000. A check list of Japanese spiders (ver. 2000). Kishidaia, 78: 79-142. (In Japanese)

Yaginuma, T. 1960. Spiders of Japan in Colour. Hoikusha, Osaka, 186 pp., 56 pls., 8 appends. (In Japanese)

Yaginuma, T. 1961. Synopsis of Japanese spiders (11). Gnaphosidae. Atypus, 22: 1-7. (In Japanese)

Yaginuma, T. 1970. The spider fauna of Japan (revised in 1970). Bull. Natn. Sci. Mus., Tokyo, 13: 639-701. (In Japanese with English summary)

Yaginuma, T. 1974. Spiders of Japan in Color, rev. ed., 4th print. Hoikusha, Osaka, 206 pp., 56 pls. (In Japanese)

Yaginuma, T. 1977. A list of Japanese spiders (revised in 1977). Acta Arachnol., 27(Spec. no.): 367-406. (In Japanese with English synopsis)

Yaginuma, T. 1986. Spiders of Japan in Color, new ed. Hoikusha, Osaka, xxiv+305 pp., 64 pls. (In Japanese)

Yaginuma, T., Hirashima, Y. \& Okuma, C. 1990. Spiders. Etymology of their Scientific and Japanese Names. Kyushu Univ. Press, Fukuoka, 287 pp. (In Japanese)

Received October 9, 2001 / Accepted November 19, 2001 
よび Spintharinae Simon 1894 を本亜科の新参異名とし た. 比較のためヒメグモ科の亜科の検索表打よびヒメ グモ亜科の属の検索表を掲げた。ここで取り上げた属 のうち 2 属はこれまで日本では記録がなく， 3 属は新 属である。

2 属 3 種, アカアシヒメグモ属（新称）Nesticodes Archer 1950，アカアシヒメグモN. rufipes (Lucas 1846), チクニヒメグモ属（新称） Neottiura Menge 1868，フ タスジヒメグモN. bimaculata (Linnaeus 1767) および チクニヒメグモ（改称）N. margarita（Yoshida 1985） はすでに外国で日本産の種に使われている。

2 属, ハイイロヒメグモ属（新称）Paidiscura Archer 1950 およびタカネヒメグモ属（新称）Rugathodes Archer 1950，は新たに記録される属であり，2 種，八 イイロヒメグモP. subpallens (Bösenberg \& Strand 1906）打よび夕力ネヒメグモ $R$. nigrolimbata （Yaginuma 1972）を新たにこれらの属に移した.

3 新属, 夕カユヒメグモ属（新称）Takayus，才キ ナワヒメグモ属（新称） Nipponidion およよ゙ホシヒメ グモ属（新称）Keijia を記載し，9種，タカユヒメグ モ Ta. takayensis (S. Saito 1939)，バラギヒメグモTa. chikunii (Yaginuma 1960), 七ロ八ヒメグモTa. latifolius (Yaginuma 1960), ユノ八マヒメグモTa. yunohamensis (Bösenberg \& Strand 1906), コケヒメグ モ Ta. subadultus (Bösenberg \& Strand 1906), シモフ リヒメグモTa. lyricus (Walckenaer 1842)，ヤエヤマ ヒメグモN. yaeyamense (Yoshida 1993)，ムナボシヒ メグモ K. sterninotata（Bösenberg \& Strand 1906）およ びサトヒメグモ（改称）K. mneon (Bösenberg \& Strand 1906）をこれらの属に移した。

さらに，3 新種，オキナワヒメグモ（新称） Nipponidion okinawense, ミナミホシヒメグモ（新称） Keijia maculata およびイリオモテヒメグモモドキ（新 称）Theridula iriomotensis を記載した。

また，ロシアのサハリンから記載された Theridula albipes S. Saito 1935 をコガネヒメグモ属 Chrysso に新 たに移し，ギボシヒメグモC. rapula (Yaginuma 1960) をC. albipes の新参異名とした.さらに、コガネヒメ グモ Chrysso venusta (Yaginuma 1957) をミャンマー で記載された C. scintillans（Thorell 1895）の，サトヒ メグモ Theridion adamsoni Berland 1934 を Keijia mneon （Bösenberg \& Strand 1906）の新参異名とした．和名は それぞれ一般に使われているギボシヒメグモ，コガネ ヒメグモおよびサトヒメグモを使用する。

中国産の 11 種, Takayus kunmingicus (Zhu 1998), Ta. naevius (Zhu 1998), Ta. lushanensis (Zhu 1998), Ta. xui (Zhu 1998), Ta. linimaculatus (Zhu 1998) Ta. wangi (Zhu 1998), Ta. sublatifolius (Zhu 1998), Ta. lunulatus (Guan \& Zhu 1993), Ta. huanrenensis (Zhu \& Gao 1993), Ta. quadrimaculatus (Song \& Kim 1991), Keijia qionghaiensis (Zhu 1998)，ヨーロッパおよび北アメリ カに分布する 1 種 $K$. tincta (Walkenaer 1802)，および 北アメリカ産の 3 種 K. antoni (Keyserling 1884), $K$. alabamensis (Gertsch \& Archer 1942) および $K$. punctosparsa (Emerton 1882) を Theridion より転属し た.

日本産として記載された 3 つの種名, Theridion argyrodiforme Bösenberg \& Strand 1906, Th. indicis Bösenberg \& Strand 1906 およよ゙ Th. sagaphilum Strand 1916 を疑問名とした.

日本産のヤリグモ属（クモ目：ヒメグモ科）およびイ ソウロウグモ亜科 (pp. 183-192)

吉田 哉（テ990-2484 山形市篭田 2 丁目 7 番 16 号）

マルイソウロウグモ属 Spheropistha，ヤリグモ属 Rhomphaea およびオナガグモ属 Ariamnes を属として 復活させ, イソウロウグモ属 Argyrodes とと屯にイソ ウロウグモ亜科として扱い, 検索表および比較のため の表を掲げた。

ヤリグモ属に属する 4 種を日本より記録した。その うち 2 種, タテスジャリグモ（新称）Rhomphaea hyrcana (Logunov \& Marusik 1990) およびヒゲナガヤ リグモ R. labiata (Zhu \& Song 1991) はイソウロウグ モ属より新たに転属したあのである．前者は日本新記 録となる。 また, 夕ニカワヤリグモ(新称） $R$. tanikawai を新種として記載した。ささらに，日本産の イソウロウグモ亜科に属する 15 種の目録を付した.

日本産のミヤシタイソウロウグモ Argyrodes miyashitai Tanikawa 1998 および中国産の A. orbitus Zhu 1998 およよ゙ A. nigroris Yoshida et al. 2000，をマルイ ソウロウグモ属 Spheropistha に転属した。中国産の Argyrodes gansuensis Zhu 1998 を Argyrodes fur Bösenberg \& Strand 1906 の新参異名とした. また, 北 海道で記載されたギンイソウロウグモ Argyrodes silvicola S. Saito 1934 を疑問名とした.

ワシグモ科の 1 新属ムモントンビグモ属と既知の 1 属 ブチワシグモ属（pp. 193-200）

加村隆英 (干 567-8502 茨木市西安威 2-1-15 追手門 学院大学生物学研究室) 
ワシグモ科の 2 属を報告した。 1 新属をSanitubius ムモントンビグモ属（新称）と命名して記載し, Sanitubius anatolicus (Kamura 1989) n. comb.ナミトン ビグモの所属を Herpyllus から移した。 Kishidaia Yaginuma 1960 ブチワシグモ属は Poecilochroa Westring 1874 の新参シノニムと見なされていたが,
これを有効な属名と考えて再記載した。同時に， Kishidaia conspicua (L. Koch 1866) n. comb. と $K$. coreana (Paik 1992) n. comb. の所属を Poecilochroa か ら移した。なお， Sanitubius anatolicus, Kishidaia albimaculata (S. Saito 1934) ヨッボシワシグモ，およ び K. conspicua の図を示した.

\section{書 評 Book Reviews}

\section{昆虫之気象}

桐谷圭治 著 (2001)

成山堂書店, 四六版, $177 \mathrm{pp}$.

ISBN 4-425-55101-X，1,600 円（税別）

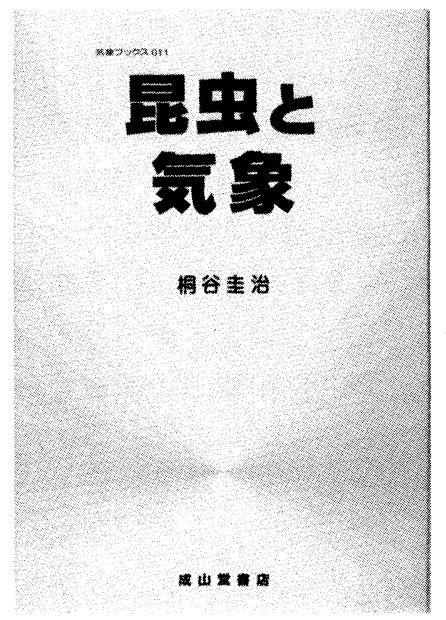

スズミグモやコガネ グモなど南方系クモの 分布北上が話題となっ ている. 地球温暖化や ヒートアイランド現象 がその一因と想像され る。クモは变温動物で あるため，気温など気 象条件の影響を強く受 ける.しかし，クモと 気象之の関係の研究は 多くなく，昆虫につい て蓄積されたデータや 理論は大いに参考になるだろう。気象ブックスシリー ズ 011（最初に 0 が付くのは 100 冊まで出す計画だと いう）として「昆虫と気象」と題するタイムリーな一 般向けの本が出た。標題は「昆虫」であっても，ご安 心下さい．ちゃんとクモ屯登場します（多くはありま せんが）。そもそ屯著者の桐谷圭治博士は，イネの害 虫であるッマグロヨコバイの天敵として，クモが重要 な役割を果していることを明らかにした方であり，こ の仕事を始めとして，打もに個体群生態学を基礎にし た害虫管理（防除）の仕事に携わって来られた．

本書の約 $2 / 3$ を占める第一章「虫たちと気象」で は，害虫を中心として，昆虫の発生に気象がどのよう に影響するかを扱っている。害蚛防除のためには，発 生を予測することが大事だが，気象条件と発生の見た 目の関係を調へてて成功しない. 食物や天敵, 病気, 生息地などへの影響を介して作用しており，そのメカ
ニズムを解き明かすことが重要であることを示してい る.こう紹介すると堅苦しい内容だと誤解されそうだ が，登場するのは打あに著者が関わって来た虫たちで あり，当時のエピソードを交えながら物語風に話を進 めているので，実に楽しく読める．いくつか例を紹介 しょう。アアリカで大発生するバッ夕は, 大発生する と形態や習性屯変わり，植物を食い尽くしながら大群 で移動するため，人々に恐れられている，日本であ 15 年ほじ前に，鹿児島県の馬毛島でトノサマバッ夕 が大発生し，その始まりから終息までの顛末が語られ ていて興味深い（標題「二つの顔をあつバッ夕」）。 ウ ンカは中国大陸から海を越えて飛来しイネに被害をむ たらすが，江戸時代には飢饉の原因ともなった（「日 本に定着できない密航者」)。サトイモやダイズの大害 虫である八スモンヨトウに対するコサラグモのアッと 驚く働き（「ハスモンヨトウとコサラグモ」; Nakasuji et al. (1973)参照)。アメリカシロヒトリは，日本に侵 入後 50 年あまり経つが，この間に日長反応が変化し て日本の気候に適応し，いわば「ヤマトシロヒトリ」 へと進化した (「アメリカシロヒトリの季節適応」).

第二章「虫たちと温度」と第三章「地球温暖化と昆 虫」では，地球環境の变化とくに温暖化という世界的 な緊急問題を取り上げている。著者はここ数年あまり, 温暖化が昆虫の発生に及ぼす作用を通じて私たちの生 活にも影響するという視点でこの問題に取り組んでい る。温暖化が昆虫に与える影響として，分布域の北上 や発生回数の増加などが挙げられる。分布の北限が北 上しているいくつかの例を示している中で, 清水ら （2001）によるタイリクヒメ八ナカメムシの研究を詳 しく紹介している，彼らは，この捕食性のカメムシの 分布之気象条件の関係を精細に解析し，本種の分布拡 大がヒートアイランド現象によるあのであると考察し ており,クモの北上を調べる時にたいへん参考になる. 著者は昆虫などの発生回数（年間世代数）を予測す 